\title{
Arthropod diversity in Lama forest reserve (South Benin), a mosaic of natural, degraded and plantation forests
}

\author{
THIBAULT LACHAT ${ }^{1, *}$, SERGE ATTIGNON ${ }^{1,2}$, \\ JULIEN DJEGO ${ }^{2}$, GEORG GOERGEN ${ }^{3}$, PETER NAGEL ${ }^{1}$, \\ BRICE SINSIN $^{2}$ and RALF PEVELING ${ }^{1}$ \\ ${ }^{1}$ Institut für Natur-, Landschafts- und Umweltschutz (NLU) - Biogeographie, Universität Basel, St. \\ Johanns-Vorstadt 10, 4056 Basel, Switzerland; ${ }^{2}$ Laboratoire d'Ecologie Appliquée, Faculté des Sci- \\ ences Agronomiques (FSA), Université d'Abomey-Calavi, Cotonou, Benin; ${ }^{3}$ International Institute of \\ Tropical Agriculture (IITA), Biodiversity Centre, Cotonou, Benin; *Author for correspondence \\ (e-mail: thibault.lachat@unibas.ch; fax: + +41-61-267-0801; phone: + +41-61-267-0800)
}

Received 18 November 2003; accepted in revised form 25 June 2004

Key words: Arthropod assemblages, Biodiversity conservation, Dahomey gap, Degraded forest, Forest plantations, Indicator species, Natural forest

\begin{abstract}
Arthropod assemblages were examined in Lama forest reserve, a protected area situated in the Dahomey gap, southern Benin, composed of plantations, degraded forest and remnants of natural forest. The objectives were to compare assemblages in relation to forest type and use, to elucidate the value of forest plantations for biodiversity conservation and to identify indicator species for specific forest habitats. Arthropods were collected over an 11-month period, using standardized sets of traps (pitfall, emergence, Malaise and flight intercept traps). Nine different habitats were studied, including natural and degraded forest, forest plantations (Tectona grandis and Senna siamea) of different age, and isolated forest fragments. Our analysis focused on detritivorous and xylophagous arthropods but also included ground beetles and heteropterans, totalling 393 species. We found no differences in species richness among natural and degraded forest habitats in the centre of the reserve (Noyau central). Outside of the Noyau central, species richness was highest in old teak plantations and isolated forest fragments and lowest in young teak and fuelwood plantations. Detrended correspondence analysis (DCA) separated three main groups: (1) natural forest, (2) degraded forest and young plantations, and (3) old plantations and isolated forest fragments. Multiple regression of DCA scores of the first two axes on environmental variables identified one natural and three disturbance-related predictors of arthropod assemblages in Lama forest: soil type (texture), canopy height, naturalness (proportion of Guineo-Congolian plant species) and understorey vegetation cover. We identified 15 indicator species for six different forest habitats. The highest numbers were found in abandoned settlements and old teak plantations. $\beta$-diversity was similar among the three DCA ordination groups (degraded forest excluded). Values for $\beta$-diversity were relatively high, suggesting that all major forest habitats contribute significantly to regional species pools and should therefore be protected. To enhance arthropod diversity, we propose that management practices in Lama forest should aim to encourage the development of species-rich understorey vegetation of the Guineo-Congolian phytogeographical region.
\end{abstract}

\section{Introduction}

West African forests are listed among the 25 hotspots considered as priority areas for biodiversity conservation (Myers et al. 2000). At the same time, there 
is consensus that secondary forests are becoming increasingly important for biodiversity conservation (Zapfack et al. 2002; Gemerden et al. 2003), and that the contribution of forest plantations to the conservation of tropical forests must be evaluated.

Forest plantations are extending world-wide. Since 1990, the area planted has quadrupled. In Africa, plantations account for only $1.2 \%$ of the total forest cover (FAO 2000), but the proportion in Benin is relatively high $(4.2 \%)$. Forest plantations provide a range of forest products on a relatively limited land surface, and can therefore contribute to reducing deforestation and degradation of natural forests (FAO 2001). Being a man-made type of forest, plantations are considered to support low biodiversity and hence be of little interest for biodiversity research and conservation. Thus, only few studies on the biodiversity in tropical forest plantations have been completed to date (e.g. Watt et al. 1997; Lawton et al. 1998; Davis et al. 2001). These studies showed that forest plantations are not necessarily "biodiversity deserts' (Speight and Wylie 2001) but that they can support a rich and varied fauna. The importance of tropical forest plantations for the conservation of wildlife and as nuclei for natural forest regeneration has been demonstrated in Madagascar (Goodman et al. 1996), Sri Lanka (Ashton et al. 1993), Thailand (Elliott et al. 1998) and Australia (Tucker and Murphy 1997).

Several authors studied the response of insects (ants, termites, moths, dung and carrion beetles) to the degradation of tropical forests (e.g. Nummelin and Hanski 1989; Holloway et al. 1992; Vasconcelos et al. 2000; Eggleton et al. 2002). These studies showed that the composition and species richness of arthropod assemblages vary depending on disturbance levels, regional species pools and the spatial and temporal scale of the study. However, little information is available on the effects of different forest management regimes on the composition of arthropod assemblages in West Africa.

As one of the last remnants of natural forest within the Dahomey gap (Ballouche et al. 2000), and an important refuge for several endangered plants and animals, Lama forest reserve is of key concern for biodiversity conservation in Benin. Only few studies have been conducted so far, the majority focusing on natural forest. Despite their larger size, degraded forests and forest plantations have received little attention. With the exception of litter-dwelling arthropods (Attignon et al. 2004) and butterflies (Fermon et al. 2001), arthropod assemblages have not been well studied, let alone surveyed in different habitat types and successional stages of forest in the reserve.

The goal of the present study was to enhance the scientific understanding of the Lama forest arthropod fauna as a basis for improved, conservation-oriented forest management. The specific objectives were (1) to compare arthropod diversity and assemblages in the principal forest types of Lama forest, (2) to assess the value of forest plantations for biodiversity conservation and (3) to identify indicator taxa for specific forest habitats. 


\section{Materials and methods}

Study site

The Lama forest reserve is situated about $80 \mathrm{~km}$ north of Cotonou $\left(6^{\circ} 55.8^{\prime}\right.$ to $6^{\circ} 58.8^{\prime} \mathrm{N}$ and $2^{\circ} 4.2^{\prime}$ to $2^{\circ} 10.8^{\prime} \mathrm{E}$ ), covering an area of 16,250 ha in a shallow depression between the Allada and Abomey plateaus. The forest is located in the Dahomey gap, a low rainfall zone separating the western and eastern part of the humid Guineo-Congolian evergreen and semi-evergreen forests of West and West-central Africa (White 1983). The climate is relatively dry (ca. $1200 \mathrm{~mm}$ rainfall), with a pronounced dry season from November to March (Sayer et al. 1992). The prevailing soils are hydromorphic vertisols rich in nutrients and clay, as well as sandy ferralsols. The natural vegetation is a semi-deciduous forest, belonging to the drier peripheral semi-evergreen Guineo-Congolian rain forest system (White 1983).

Despite having been legally protected since 1946, deforestation for agriculture in Lama forest continued until 1988, leading to the reduction of natural forest cover from 11000 to 1900 ha. Since then, a central part covering 4800 ha, the so-called Noyau central, lies under strict protection. Peasants living in the Noyau central were resettled in nearby agroforestry schemes. Reflecting the traditional farming system, the Noyau central is composed of a small-scale mosaic of natural and degraded forest patches of variable size and successional stages (Specht 2002). The Noyau central is surrounded by young and old teak plantations (7000 ha, Tectona grandis) and fuelwood plantations (2400 ha, mainly Senna siamea, interspersed with $T$. grandis, and a few stands of Acacia auriculiformis) (Figure 1). The present study focused on nine different forest types representing all major habitats within the reserve boundaries plus a few forest remnants outside of the reserve. Five forest types were situated within the Noyau central and four outside:

1. Semi-deciduous forest (1937 ha) is dominated by tree species such as Afzelia africana, Ceiba pentandra, Dialium guineense, Diospyros mespiliformis, Drypetes floribunda, Celtis brownii, Mimusops andongensis. The understorey vegetation can be dense and canopy height reaches 16-21 $\mathrm{m}$ (Table 1).

2. Cynometra megalophylla lowland forest ( $<100$ ha) grows in seasonally flooded areas. This forest is characterized by $C$. megalophylla and other plants adapted to seasonal flooding. The understorey vegetation is usually less dense than in semi-deciduous forest.

3. Anogeissus leiocarpa dry forest (1222 ha) is a secondary forest developing on former slash-and-burn patches. A. leiocarpus can reach $20 \mathrm{~m}$ in height and promotes the establishment of shade-tolerant plants.

4. Abandoned settlements (166 ha) of the resettled population present a characteristic vegetation type composed of cultivated trees such as oil palm (Elaeis guineensis) and guava (Psidium guajava), and secondary regrowth.

5. Perennial Chromolaena odorata thicket (1452 ha) grows on former farmland. $C$. odorata is an alien, invasive species of neotropical origin 


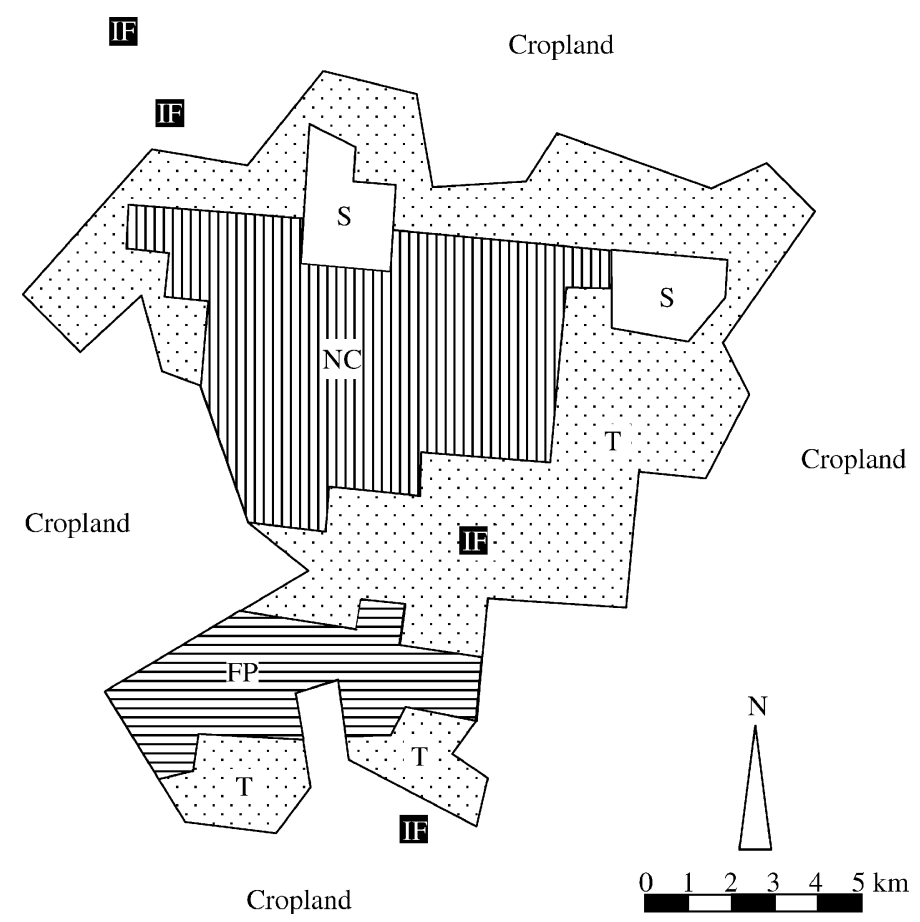

Figure 1. Schematic view of Lama forest reserve. NC, Noyau central; T, Teak plantations; FP, Fuelwood plantations; S, Settlements; IF, Isolated forest fragments (the latter not to scale).

encroaching open-canopy forest patches, clearings, as well as fallow land. It is rapidly shaded out if the forest canopy cover exceeds about $40 \%$.

6. Young teak plantations (7200 ha) were planted between 1985 and 1995 on vertisol around the Noyau central.

7. Old teak plantations (2200 ha) were planted between 1955 and 1965 on sandy ferralsol (transition between vertisols in the valley and ferralitic soils on the surrounding plateaus).

8. Fuelwood plantations (2400 ha) were planted between 1988 and 1996. They are composed of S. siamea, $T$. grandis and A. auriculiformis.

9. Most isolated forest fragments are located outside of the reserve. These widely scattered sacred groves are embedded in a matrix of farmland and degraded savannah. They are used as ceremonial places and remain in a relatively natural state. The remnants are usually very small (1-2 ha).

Sampling sites were selected according to three criteria: (1) spatial representativeness, (2) patch size and (3) accessibility. Each forest type was represented by four replicates. Thus, the total number of sites was 36 (Table 1). Distances between sites of the same forest type ranged from 0.3 to $19.0 \mathrm{~km}$. A minimum distance of $20 \mathrm{~m}$ (small patches) or $50 \mathrm{~m}$ (large patches) was maintained between sampling sites and patch borders. 


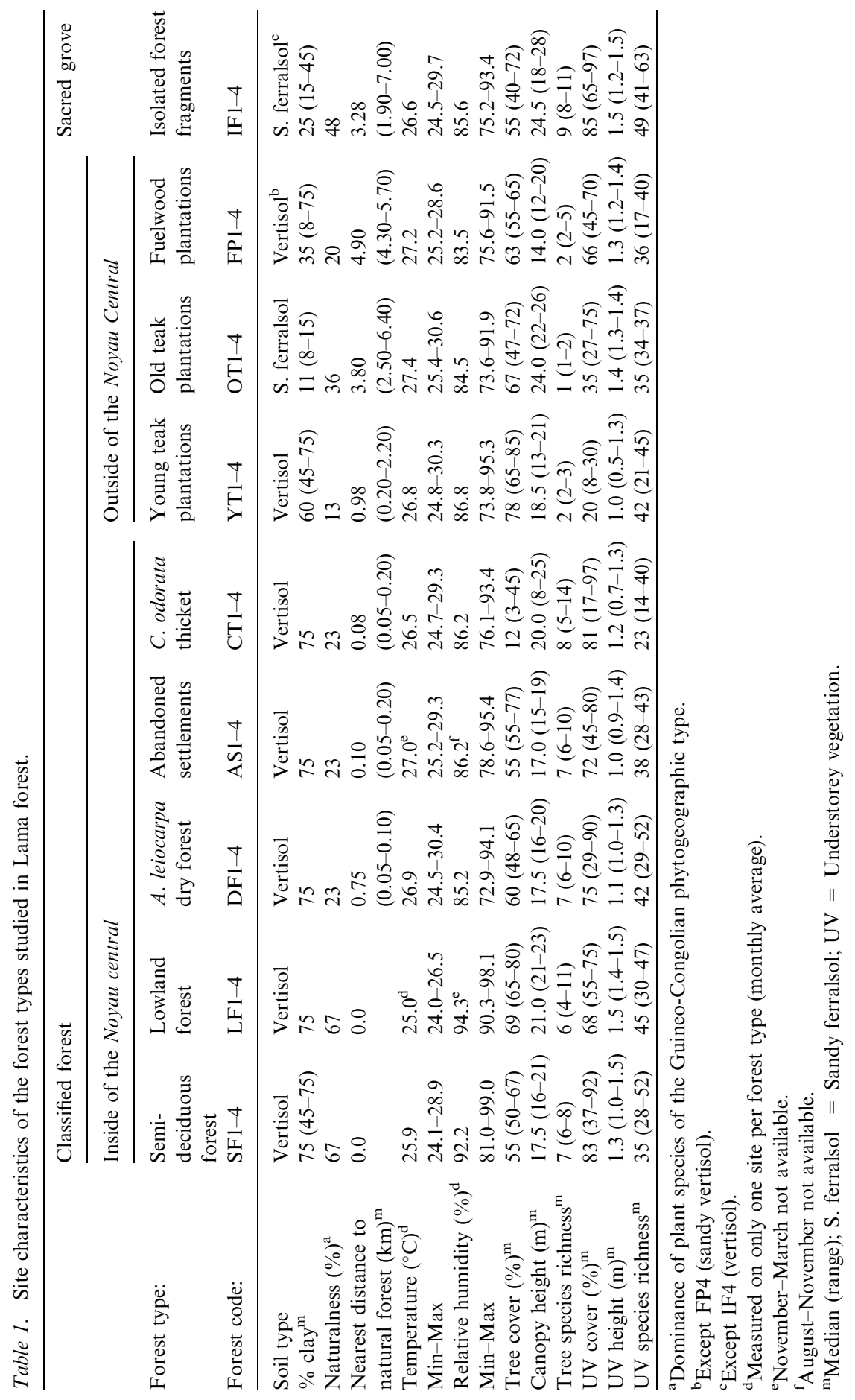


A botanical survey was also conducted within the scope of our study, using the Braun-Blanquet system. Two hundred ninety plant species in 77 families were sampled (unpublished data).

\section{Sampling methods}

On each site, we installed an equal number of sampling devices, comprising (1) three funnel pitfall traps, each consisting of a collecting jar inside a plastic sleeve, an $11 \mathrm{~cm}$ diameter funnel and a transparent plastic roof $20 \mathrm{~cm}$ in diameter (Southwood 1978), (2) one Malaise trap (after Townes 1972) with a $1.5 \mathrm{~m}^{2}$ black vertical mesh panel, (3) one flight intercept trap intercepting insects flying between 1.0 and $1.5 \mathrm{~m}$ above the ground, consisting of two crossed black vertical mesh panels, each measuring $0.25 \mathrm{~m}^{2}$ $(0.5 \times 0.5 \mathrm{~m})$, and top and bottom funnels $50 \mathrm{~cm}$ in diameter (Wilkening et al. 1981), and (4) one pyramid-shaped emergence trap (ground photoeclector) covering an area of $0.75 \mathrm{~m}^{2}(\approx 0.86 \times 0.86 \mathrm{~m})$, equipped with a collecting jar on the top and one pitfall trap (Mühlenberg 1993). The traps were spaced out along $30 \mathrm{~m}$ north-south transects. The placement design was similar at all sites. We used formalin $(0.5 \%)$ as a preservative, adding some detergent to lower the surface tension. A preliminary 2-week sampling was conducted in May 2001 to establish the methodology. The sampling period for the present study was 1 week per month from June 2001 to April 2002. Specimens were sorted, counted, labelled and stored in alcohol (75\%) for later identification.

\section{Sorting scope and identification}

Among the wide range of invertebrates sampled, we focused on detritivorous and xylophagous arthropods because of their important role in nutrient cycling in forest ecosystems (Didham et al. 1996). These taxa comprised 14 coleopteran families, as well as representatives of Isoptera, Diplopoda and Isopoda. We also included epigeal predators (Carabidae and Chilopoda), omnivorous beetles (Tenebrionidae) and both herbivorous and predatory bugs (Heteroptera). These additional taxa were retained for a more comprehensive characterization of arthropod assemblages and because some have been used as representative indicators in previous biodiversity assessments (Duelli and Obrist 1998; Giulio et al. 2001; Rainio and Niemelä 2003).

All arthropods were first sorted to 'morphospecies' (sensu New 1998) and then taxonomically identified at the International Institute of Tropical Agriculture (IITA) in Benin. Voucher specimens were deposited at the IITA Biodiversity Center and partly at the Museum of Natural History, Basel, Switzerland. The analysis was done at the morphospecies level for taxa with difficult taxonomy (e.g. most Diplopoda). 


\section{Environmental variables}

Soils were classified according to the FAO system (FAO-UNESCO 1974), and the percentage of clay (soil texture) was estimated by touch. Temperature $\left({ }^{\circ} \mathrm{C}\right)$ and relative humidity $(\mathrm{RH})$ were recorded every hour from April 2002 to March 2003, using one data logger (Hobo Pro RH/Temp) per forest type. Loggers were attached to tree trunks about $1 \mathrm{~m}$ above ground level. The naturalness (sensu Angermeier 1999) of the different forest types was calculated based on the proportion of plant species belonging to the Guineo-Congolian phytogeographical region. We also determined cover, height and species richness of the main vegetation strata (Table 1). The nearest distance between sampling sites and natural forest patches was measured with a geographic information system (ArcView 3.1), using the vegetation map of Specht (2002) (Table 1).

\section{Measures of diversity}

We used species richness as a measure of $\alpha$-diversity (the number of species within a habitat). $\beta$-diversity (the degree of change in species composition between habitats) was evaluated for selected groups of forest habitats according to Whittaker's formula $\beta_{\mathrm{w}}=\gamma / \bar{\alpha}$, where $\gamma$ is the species pool within a group of habitats ( $\gamma$-diversity) and $\bar{\alpha}$ is the average number of species per site (Whittaker 1960).

\section{Data analysis}

We used the total catch per taxon and per sampling site for statistical analyses. This was done by pooling specimens from all sampling periods and traps within sampling sites.

One-way analysis of variance (ANOVA) was conducted to test differences in arthropod assemblages among forest types (Zar 1999), followed by Bonferroni multiple comparison of means. In view of an unfavourable ratio between factor levels $(n=9)$ and replicates $(n=4)$, we also performed a post hoc power analysis (SPSS 12.0).

To determine the similarity of forest types based on their arthropod assemblages, we performed detrended correspondence analysis (DCA) (Hill and Gauch 1980), using PC-ORD 4.27 (McCune and Mefford 1999). Abundances of species rarer than $F_{\max } / 5$ (where $F_{\max }$ is the frequency of the most common species) were down-weighted in proportion to their frequency. Axes were rescaled with a threshold of zero, and the number of segments was set to 26 (default). Reciprocal averaging (RA), also known as correspondence analysis, revealed the same grouping, but DCA was preferred because it squashed the arch effect associated with RA and corrected the compression of the axis 
ends. The proportion of variance represented by the ordination axes was calculated according to an after-the-fact method, using the relative Euclidean distance (McCune and Mefford 1999). Stepwise multiple regression with forward selection (SPSS 12.0) was conducted to relate DCA ordination scores of the first two axes to the environmental variables listed in Table 1.

A hierarchical cluster analysis based on presence/absence data was employed to distinguish groups of sites in the DCA ordination plot (SPSS, 12.0, settings: Ward's method, squared Euclidean distance). Clusters were grouped in probability ellipses whose axes are proportional in length to a specified percentage of the $x$ and $y$ coordinates (Jennrich and Turner 1969). The inclusion probability was set to $p=0.90$. Computation of the ellipses was done with ArcView 3.1.

We used Mantel tests to evaluate the relationship between arthropod assemblages and the distance to the nearest natural forest patch (Mantel 1967). These tests were performed with PC-ORD 4.27 (McCune and Mefford 1999), using binary data (Sørensen distance) and Monte Carlo randomization (1000 runs).

\section{Indicator species}

Indicator species for the different forest types were determined according to Dufrêne and Legendre (1997). The method combines data on the frequency of occurrence (faithfulness) and relative abundance (concentration) of species in a particular habitat. The significance of indicator values was tested using Monte Carlo randomization (1000 runs). The threshold level for the indicator value was $25 \%$. This implies that the frequency of occurrence of a species indicative of a particular habitat must be $\geq 50 \%$, and its relative abundance therein $\geq 50 \%$ of its total abundance at all sites (Dufrêne and Legendre 1997). The significance level was $p \leq 0.01$, as proposed by the authors. The analysis was performed with PC-ORD 4.27 (McCune and Mefford 1999). Note that indicator organisms may include both species restricted to a certain habitat and those more widely distributed yet especially abundant in a particular type of forest.

\section{Estimation of true species richness}

True species richness was estimated by computing the abundance-based coverage estimator (ACE) and the incidence-based coverage estimator ICE (1000 runs) for the eleven collecting periods, using EstimateS 6.0 (Colwell 1997). The ACE is based on species with $\leq 10$ individuals in the sample (Chao et al. 1993). The corresponding ICE, likewise, is based on species found in $\leq 10$ sampling sites (Lee and Chao 1994). These estimations were the most appropriate for our data set which was characterized by a large number of singletons (species occurring with one individual only) and uniques (species occurring in one sample only). 


\section{Results}

A total of 9431 specimens belonged to the taxonomic groups examined in the present study, representing 393 species (Appendix 1). More than one third of all species were singletons, and only 14 were collected in all forest types. Seventy one percent (ACE) and 66\% (ICE) of the estimated true species number were sampled.

\section{Coleoptera}

We collected 264 species in 16 families of Coleoptera, representing $67 \%$ of the total number of species and 58\% (5499 specimens) of the total number of arthropods included in the analysis. Except for carabids, the high number of specimens was due to a few very abundant species. Of 37 scarabaeid species, six represented over $63 \%$ of all specimens. One of 17 species of Elateridae represented $97 \%$ of the total catch in this family, and one of 12 species of Scolytidae $58 \%$ of the total catch. All but one scarabaeid species of the dominant taxa were found in all forest types. Thirty eight percent of all coleopteran species were singletons. Most coleopterans were collected in isolated forest fragments (111 species, $42 \%$ of all coleopterans) and old teak plantations (94 species, 36\%), and the smallest number in young teak plantations (64 species, $24 \%$ ) and fuelwood plantations (59 species, 22\%). Forest types within the Noyau central had about the same number of coleopteran species, with an average of $81 \pm 1$ species (mean $\pm \mathrm{SE}$ ).

\section{Heteroptera}

Within 15 families of Heteroptera, we found 75 species $(19 \%$ of the total number of arthropod species analyzed) and 558 specimens $(6 \%$ of the total catch analyzed). Forty-one percent of the Reduviidae (22 species) and 54\% of the Lygaeidae (17 species) were represented by three species only. One of five species of Alydidae made up $95 \%$ of the total catch for this family. More than $41 \%$ of all heteropterans were singletons. Species numbers were highest in isolated forest fragments (32 species) and lowest in semi-deciduous forest (13 species). The other forest types within the Noyau central presented an average species number of $23 \pm 1$ (mean $\pm \mathrm{SE}$ ).

\section{Chilopoda, Isopoda, Diplopoda and Isoptera}

For the classes Isopoda, Diplopoda and Chilopoda and for the order Isoptera, the analysis was performed at the morphospecies level. Forty eight percent of all Diplopoda (27 species) were represented by only one species occurring in all 
forest types. Two of 14 species of Isopoda made up $52 \%$ of the total catch of this taxon. Only six species of Isoptera were sampled, with one species representing $96 \%$ of all specimens.

\section{Arthropod diversity}

Despite the unfavourable ratio between factor levels and replicates, the statistical power of the analyses of variance was satisfactory (0.996). Differences in species richness among forest types were significant at $p<0.001$ $\left(F_{8,27}=5.76\right)$. Isolated forest fragments and old teak plantations showed the highest number of species (Figure 2), with an average of $71 \pm 5$ and $67 \pm 2$ species, respectively (mean $\pm \mathrm{SE}$ ). Species richness was lowest in young teak $(40 \pm 6)$ and fuelwood plantations $(43 \pm 6)$. Natural and degraded forest in the Noyau central had intermediate levels of species richness, ranging from $50 \pm 2$ in C. megalophylla lowland forest to $57 \pm 2$ in abandoned settlements. Statistically significant differences were found between young plantations (teak and fuelwood) and old teak plantations or isolated forest fragments (Figure 2).

$\beta$-diversity of arthropod assemblages was computed for the three habitat (site) groups obtained by the DCA ordination (see below). Two of these groups (group one and three, Figure 3) contained two forest types each, including all old-growth forests, and one group (group two) the remaining forest types. Of these, we selected young teak and fuelwood plantations as representatives of young-growth forest. Because some groups comprised only three of the four replicate sites per forest type, we randomly excluded one replicate site of each complete sample to achieve an equal number of sites per group which is a prerequisite for comparing $\beta_{\mathrm{w}}$-diversity. Thus, each group contained three replicate sites of two different forest types $(n=6)$. $\beta$-diversity was very similar among these three groups of forest habitats, ranging from $\beta_{\mathrm{w}}=2.8$ in group three (old teak plantations and isolated forest fragments) and $\beta_{\mathrm{w}}=3.1$ in

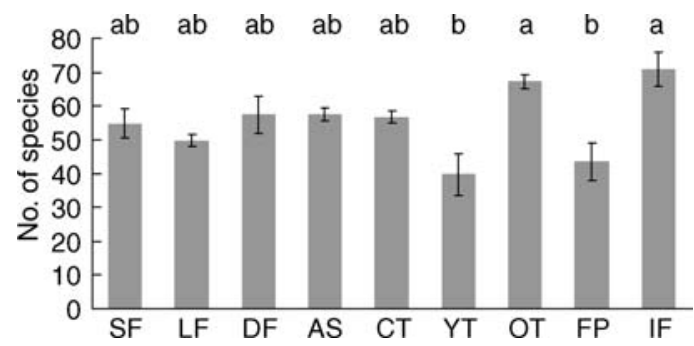

Figure 2. Species richness in nine different forest habitats in Lama forest. Bars show means $\pm \mathrm{SE}$ $(n=4)$. SF, Semi-deciduous forest; LF, C. megalophylla lowland forest; DF, A. leiocarpa dry forest; AS, Abandoned settlements; CT, C. odorata thicket; YT, Young teak plantations; OT, Old teak plantations; FP, Fuelwood plantations; IF, Isolated forest fragments. Means marked with different letters are significantly different at $p<0.05$. 


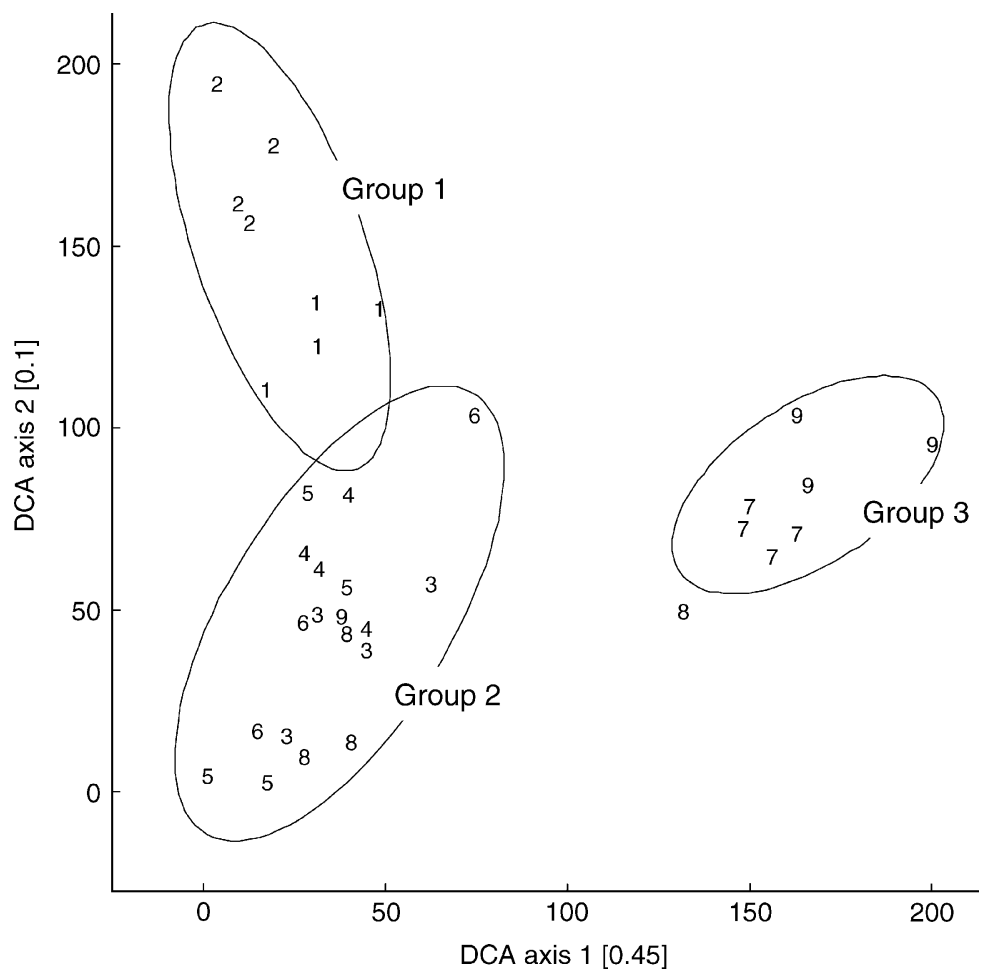

Figure 3. Detrended correspondence analysis (DCA) of sampling sites in species space proportion of variance. Groups 1, 2 and 3 are defined by probability ellipses $(p=90 \%)$. 1, Semi-deciduous forest; 2, C. megalophylla lowland forest; 3, A. leiocarpa dry forest; 4, Abandoned settlements; 5, C. odorata thicket; 6, Young teak plantations; 7, Old teak plantations; 8, Fuelwood plantations; 9 , Isolated forest fragments.

group two (young teak and fuelwood plantations) to $\beta_{\mathrm{w}}=3.2$ in group one (semi-deciduous forest and C. megalophylla lowland forest).

\section{Arthropod assemblages}

DCA of sampling sites in species space revealed three distinct groups of forest habitats: (1) natural forest, comprising semi-deciduous forest and C. megalophylla lowland forest, (2) degraded forest and young plantations, including A. leiocarpa dry forest, abandoned settlements, C. odorata thicket, young teak plantations (all but one site) and fuelwood plantations (all but one site), and (3) old teak plantations and isolated forest fragments (all but one site) (Figure 3).

The proportion of variance represented by the first axis of the DCA ordination was 0.45 . Multiple regression identified two significant predictors of DCA axis one scores, soil texture and canopy height $\left(F_{2,33}=76.6\right.$, 
$\left.R^{2}=0.823, p<0.001\right)$. The regression equation is:

$$
\text { Axis } 1=78.3-1.6(\mathrm{PC})+3.8(\mathrm{CH}) \text {, }
$$

where $\mathrm{PC}=$ Percentage of clay and $\mathrm{CH}=$ Canopy height; $t$-values for the partial regression coefficients were $-9.0(p<0.001)$ and $3.6(p=0.001)$, respectively, indicating that soil texture was the major explanatory variable in this model.

The proportion of variance represented by the second axis was 0.10 . DCA axis two scores were also best predicted by two variables only, naturalness and understorey cover $\left(F_{2,33}=49.7, R^{2}=0.751, p<0.001\right)$. For the second axis, the regression equation is:

$$
\text { Axis } 2=26.8+2.3(\mathrm{PG})-0.6(\mathrm{PU}) \text {, }
$$

where PG $=$ Percentage of Guineo-Congolian plant species and PU $=$ Percentage of understorey vegetation cover; $t$-values for the partial regression coefficients were $10.0(p<0.001)$ and $-3.3(p=0.002)$, respectively. Thus, naturalness was the more important explanatory variable.

The remaining environmental variables listed in Table 1 had no significant effect on the ordination scores.

Mantel tests revealed that arthropod assemblages of replicate sites within young teak and fuelwood plantations were not correlated with the distance to the nearest natural forest patches $\left(r_{\mathrm{s}}=0.436, p=0.260\right.$ and $r_{\mathrm{s}}=0.533$, $p=0.169$, respectively).

\section{Indicator species}

We identified 15 indicator species for six different forest habitats, ranging from one to five species per forest type (Table 2). No indicators were found for dry forest, $C$. odorata thicket and young teak plantations. The indicators included 11 species of Coleoptera, two species of Isopoda and one species each of Diplopoda and Heteroptera. Most indicator species were recorded for abandoned settlements $(n=4)$ and old teak plantations $(n=5)$.

\section{Discussion}

\section{Arthropod diversity}

Against our expectations, $\alpha$-diversity was similar among the different forest types within the Noyau central. We would have expected lower species richness in disturbed habitats such as $C$. odorata thicket. However, not only was species richness similar, but the similarity in species composition was also high, ranging from $38 \%$ (C. odorata thicket versus lowland forest) to $58 \%$ (C. odorata thicket versus dry forest) species in common (Lachat, unpublished 
Table 2. Indicator species sensu Dufrêne and Legendre (1997) for Lama forest.

\begin{tabular}{|c|c|c|}
\hline & Indicator value (\%) & $P$ \\
\hline \multicolumn{3}{|l|}{ Semi-deciduous forest } \\
\hline $\begin{array}{l}\text { Chlaenius (Chlaenites s.l.) sp. } \\
\text { (Carabidae, Chlaeniinae) }\end{array}$ & 80.0 & 0.001 \\
\hline Scolytidae sp. 9 & 58.7 & 0.001 \\
\hline \multicolumn{3}{|l|}{ C. megalophylla lowland forest } \\
\hline Stenocoris southwoodi Ahmad, Alydidae & 95.8 & 0.001 \\
\hline \multicolumn{3}{|l|}{ Abandoned settlement } \\
\hline Onthophagus sp. 1, Scarabaeidae & 66.7 & 0.001 \\
\hline Onthophagus sp. 3, Scarabaeidae & 54.8 & 0.003 \\
\hline Sisyphus sp. 1, Scarabaeidae & 66.7 & 0.004 \\
\hline Elateridae sp. 3 & 31.1 & 0.007 \\
\hline \multicolumn{3}{|l|}{ Old teak plantations } \\
\hline $\begin{array}{l}\text { Hoplolenus obesus (Murray, 1858) } \\
\text { (Carabidae, Oodini) }\end{array}$ & 72.2 & 0.001 \\
\hline Trochalus sp. 1, Scarabaeidae & 75.0 & 0.008 \\
\hline Trochalus sp. 2, Scarabaeidae & 72.1 & 0.002 \\
\hline Tenebrionidae sp. 24 & 60.9 & 0.007 \\
\hline Diplopoda sp. 1 & 31.3 & 0.002 \\
\hline \multicolumn{3}{|l|}{ Fuelwood plantations } \\
\hline Isopoda, Eubelidae sp. 3 & 68.9 & 0.005 \\
\hline Isopoda, Eubelidae sp. 5 & 61.5 & 0.001 \\
\hline \multicolumn{3}{|l|}{ Isolated forest fragments } \\
\hline $\begin{array}{l}\text { Tetragonoderus (s.str.) } \\
\text { quadrimaculatus Gory, } 1833 \\
\text { (Carabidae, Cyclosomini) }\end{array}$ & 87.5 & 0.001 \\
\hline
\end{tabular}

No indicator species were found for A. leiocarpa dry forest, $C$. odorata thickets and young teak plantations.

data). This suggests a high connectivity between natural, secondary and degraded parts of the Noyau central whose spatial structure is characterized by contiguous patches of variable size, sometimes covering less than 1 ha (Specht 2002 ). Moreover, forest cover was relatively high $(\leq 45 \%)$ even in degraded patches, which would be expected to facilitate movements between forest habitats. This is corroborated by observations in the Amazon which showed that secondary growth reduces the barrier effect of cleared forest for forest dung and carrion beetles (Klein 1989).

Our results confirm those of other studies that found no major difference in species richness of arthropod assemblages between primary forest and secondary and/or degraded (logged) forest (e.g., Nummelin and Hanski 1989; Holloway et al. 1992; Kalif et al. 2001).

Significant differences in species richness were found only among forest habitats outside of the Noyau central (Figure 2). Notably, species richness in old teak plantations was as high as in forest fragments and in the Noyau central, which demonstrates the importance of old teak for arthropod diversity conservation. The low species richness in young teak and fuelwood plantations came as no surprise. These forests are more exposed to silvicultural practices. 
Moreover, despite a fire exclusion strategy adopted by the forestry authorities, agricultural fires sometimes escape into young teak and fuelwood plantations.

$\beta$-diversity was similar between the three groups obtained by the DCAordination (natural forest, young plantations, old plantations and isolated forest fragments). Furthermore, $\beta_{\mathrm{w}}$-values were relatively high (2.8-3.2), compared to a theoretical minimum of $\beta_{\mathrm{w}}=1$ (each species occurs on all sites) and a maximum of $\beta_{\mathrm{w}}=6$ (each species occurs on one site only) for $n=6$ sites per group. $\beta$-diversity - hence species turnover - increases with increasing spatial heterogeneity, resource selectivity and the diversity of refugia available to rare species (Stanton 1979; Deshmukh 1986). From a conservation point of view, high $\beta$-diversity implies that the preservation of diversity is most effective if habitats are protected entirely.

\section{The importance of plantations for biodiversity conservation}

Several modifications to the design and management of tropical plantations have been proposed that may enhance regional biodiversity without compromising economic benefits (reviewed in Lamb 1998). Among the various approaches, two are pertinent to Lama forest: the establishment of plantations in the vicinity of natural forest - which may act as a reservoir and source of forest species - and the development of understorey vegetation. The second option is only feasible for long-rotation sawlogs such as teak. The growth of understorey vegetation and a concomitant increase in biodiversity is enhanced by the selective harvesting of logs which creates gaps for plant colonization. In Lama forest, this process seems to be supported by the fire exclusion practice. Contrary to timber plantations, understorey development is unlikely in short-rotation forests such as fuelwood plantations (Lamb 1998). Fuelwood in Lama forest is harvested at an age of 20 years or less. These plantations obviously contribute less to biodiversity conservation, as reflected by the low species richness found in our study. Even though, the production of fuelwood itself may reduce the pressure on natural forest resources.

The evidence provided in the present study shows that old teak plantations are important habitats for forest species. This is supported by the presence of typical forest specialists such as Paussus excavatus, P. liber and P. bicornis (Carabidae, Paussinae). Similar observations were made in mature plantations of endemic hardwood in Cameroon where butterfly assemblages were undistinguishable from those found in natural forest (Stork et al. 2003). An elevated arthropod diversity in old plantations may have consequences not only from a biodiversity conservation but also from a pest management perspective. A high degree of naturalness and/or close distance to natural forest may benefit natural enemies of forest pests, thereby reducing the risk of infestations of plantation forests (Speight and Wylie 2001). 
The distance between natural forest and sampling sites in young teak plantations varied from 0.2 to $2.2 \mathrm{~km}$, and the distance to sampling sites in fuelwood plantations from 4.3 to $5.7 \mathrm{~km}$. Thus, one might hypothesize that assemblages within plantations differ depending on their distance to the nearest natural forest patch. Yet, a border effect was dismissed on the basis of the Mantel tests performed, suggesting that plantations adjacent to the Noyau central may act as dispersal corridors. However, our study design was not conceived to monitor movement pathways between forest patches.

\section{Influence of environmental variables on arthropod assemblages}

Arthropod assemblages in the different forest types were most strongly related to soil type (DCA axis 1), a natural site character, and to naturalness of the vegetation (DCA axis 2), an indicator of disturbance. The other two statistically significant explanatory variables were canopy height (DCA axis 1) and understorey cover (DCA axis 2), representing disturbance indicators related to land use and management.

Soil may have influenced arthropod assemblages in two ways. First, the prevailing vertisols show distinct seasonal swelling-shrinking cycles. During the dry season, they harden and form deep cracks. In the rainy season, they are saturated with water, leading to flooding in depressions. This in turn might reduce the habitat available to epigeal species not tolerating temporary flooding, forcing them to retreat to mounds of the so-called gilgai micro relief (irregular land surface with alternating mounds and depressions in areas with vertisol). To the contrary, physical properties of the sandy ferralsols in old teak plantations and isolated forest fragments do not change dramatically between seasons, and the soil may offer suitable habitats throughout the year. Second, soil influences arthropods indirectly by affecting the vegetation. However, ordination of our vegetation data did not clearly segregate plant associations of forests stocking on vertisol and ferralsol (Djego, unpublished data), suggesting that soil type had a more pronounced influence on arthropod assemblages than on plant associations.

The importance of soil as a co-determinant of arthropod assemblages was also evidenced by the sites plotted outside of the corresponding probability ellipses in the DCA ordination (Figure 3). For example, the soil of one of the fuelwood plantation sites (label 8) was a sandy vertisol. This site plotted next to group three which also comprised sites on ferralsol. Likewise, the only isolated forest fragment (label 9) located on vertisol - and being embedded in a matrix of young teak plantations - was plotted together with group two sites, all of which shared the same soil. The remaining environmental predictors of arthropod assemblages in Lama forest (naturalness, canopy height, understorey vegetation cover) are related to land use and silvicultural practices. Naturalness is an indicator of human disturbance (clearing for agriculture, conversion to plantation forests and other land uses). Highly disturbed parts of Lama forest have a higher proportion of plant species with wide (sometimes pantropical) 
distribution, while Guineo-Congolian species dominate in less disturbed parts. Naturalness increases not only from degraded to natural forest, but also from young to old plantations. Unfortunately, little is known about the biogeography of the arthropod species sampled, which makes it difficult to define geographic types and to draw parallels with phytogeographic types.

Canopy height reflects a succession towards old-growth forest. The tallest canopy trees were found in old teak plantations and isolated forest fragments (cf., Table 1). The similarity in vegetation structure may have contributed to the high similarity of arthropod assemblages among these forests.

The development of understorey vegetation is a characteristic of old-growth stands (Lamb 1998). However, understorey cover in Lama forest was highly variable within and among the different forest types (Table 1) and should therefore be interpreted with caution. For example, disturbed, open-canopy forests were often dominated by uniform $C$. odorata thicket, whereas a diversity of native, shade-tolerant plants prevailed in closed-canopy forests (Djego, unpublished data). Thus, understorey cover alone appears to be an insufficient predictor of arthropod assemblages, but together with naturalness it defines environmental conditions relevant to their composition.

\section{Edge effects in old teak plantations and isolated forest fragments}

In contrast to other studies (Didham et al. 1998; Barbosa and Marquet 2001), the highest species richness was encountered in isolated forest fragments and old teak. Moreover, the similarity of arthropod assemblages was high, despite long distances among replicate sites $(16-19 \mathrm{~km})$.

Another common trait of these forest types - apart from soil type and naturalness - is their adjacency to open country (degraded savannah and/or cropland). Forest edges are likely to attract arthropods from open landscape as well as forest, thereby increasing overall species richness (Laurance et al. 2002). Some forest species may even increase in abundance near edges, in particular those adapted to the microclimate prevailing in open forest or treefall gaps (Kapos 1989; Laurance et al. 2002). Such edge effects - along with the combined effect of the four environmental explanatory variables - may explain the high diversity and distinctiveness of arthropod assemblages in old teak plantations and isolated forest fragments.

\section{Indicator species}

Indicator species have been defined as taxa that 'mirror changes in a wider array of groups as a consequence of environmental change' or that 'reflect overall diversity and complexity of an assemblage' (New 1998). The idea to focus on indicator species is also owed to limitations in processing and identifying the huge numbers of samples typically collected during invertebrate 
surveys. The four most important criteria for choosing invertebrate indicators are that they have a well-known taxonomy and ecology, are accessible to sampling and respond to environmental changes (New 1998). Strictly speaking, none of the species identified in the present study fulfils all of these criteria. At this initial stage of research, they are therefore simply considered as species characteristic of certain forest habitats. Their role as indicators of successional changes requires validation in future monitoring programmes.

Notably, the highest numbers of indicators were found in abandoned settlements and old teak plantations. This can be interpreted as an indication of the importance of these two forest types to regional biodiversity.

Taxonomically, most species belong to the family Scarabaeidae (chafers, Melolonthinae, and dung beetles, Scarabaeinae). Dung beetles have often been used as indicators because of their reliance on vertebrate dung or carrion and their sensitivity to habitat disturbance (Klein 1989; Nummelin and Hanski 1989; Hill 1995). Carabidae are also well represented. While being common indicators in temperate ecosystems, their suitability for tropical forests is as yet not well established (Rainio and Niemelä 2003).

\section{Conclusion}

This study provides a first overview of the arthropod diversity in Lama forest reserve, one of the last and largest vestiges of natural forest in southern Benin, and highlights its importance for biodiversity conservation. No differences in arthropod species richness were found among habitats within the Noyau central, a small-scale mosaic of natural and degraded forest. However, great differences were observed among forest plantations separating the Noyau central from the matrix of agricultural land. We identified four environmental variables as significant predictors of arthropod assemblages. Of these, soil type is a natural factor promoting high species richness in old plantations and isolated forest fragments. The remaining variables naturalness, understorey cover and canopy height are related to silvicultural practices and are therefore amenable to an improved, conservation-oriented forest management. To enhance arthropod diversity in Lama forest, we propose that management practices should aim to encourage the development of species-rich understorey vegetation of the Guineo-Congolian phytogeographical region. Animals higher up the food chain, in particular insectivorous reptiles, birds and mammals, may also benefit from increased arthropod diversity. In this respect, arthropod conservation is not an end in itself but a contribution to overall biodiversity conservation.

\section{Acknowledgements}

This study was funded by the Swiss National Science Foundation and the Swiss Agency for Development and Cooperation. It was carried out in the 
framework of the project BioLama. We thank all BioLama staff for their support, especially M. Guedegbé, C. Houngbedji, L. Konetche and D. Weibel. We are grateful to P. Houayé, R. Akossou, D. Honfozo, H. Hodonou and A. V. N'velin of the Office National du Bois for their backing, to Gwendoline Altherr for statistical help and to C. Schmid for the determination of Isopoda. Further, J. Refisch and two anonymous referees are acknowledged for helpful comments on an earlier version of this article.

\section{References}

Angermeier P.L. 1999. The natural imperative for biological conservation. Conserv. Biol. 14: $373-$ 381.

Ashton P.M.S., Gunatilleke C.V.S. and Gunatilleke I.A.U.N. 1993. A shelterwood method of regeneration for sustained timber production in Mesua-Shorea forest of Southwest Sri Lanka. In: Erdelen W., Preu C., Ishwaran C.M. and Bandara M. (eds), Ecology and Landscape Management in Sri Lanka. Margraf Verlag, Weikersheim, pp. 255-274.

Attignon S.E., Weibel D., Lachat T., Sinsin B., Nagel P., Peveling R. 2004. Leaf litter breakdown in natural and plantation forests of the Lama forest reserve in Benin. Appl. Soil Ecol. in press.

Ballouche A., Akoègninou A., Neumann K., Salzmann U. and Sowunmi M.A. 2000. Le projet 'Dahomey Gap: une contribution à l'histoire de la végétation au Sud-Bénin et Sud-Ouest du Nigeria. Berichte des Sonderforschungsbereichs 268: 237-251.

Barbosa O. and Marquet P.A. 2001. Effects of forest fragmentation on the beetle assemblage at the relict forest of Fray Jorge, Chile. Oecologia 132: 296-306.

Chao A., Ma M.-C. and Yang M.C.K. 1993. Stopping rules and estimation for recapture debugging with unequal failure rates. Biometrica 80: 193-201.

Colwell R.K. 1997. EstimateS: Statistical Estimation of Species Richness and Shared Species from Samples. http://viceroy.eeb.uconn.edu/estimates.

Davis A.J., Holloway J.D., Huijbregts H., Krikken J., Kirk-Spriggs A.H. and Sutton S.L. 2001. Dung beetles as indicators of change in the forests of northern Borneo. J. Appl. Ecol. 38: 593616.

Deshmukh I. 1986. Ecology and Tropical Biology. Blackwell Scientific Publications, Boston.

Didham R.K., Ghazoul J., Stork N.E. and Davis A.J. 1996. Insects in fragmented forests: a functional approach. Tree 11: 255-260.

Didham R.K., Hammond P.M., Lawton J.H., Eggleton P. and Stork N.E. 1998. Beetle species responses to tropical forest fragmentation. Ecol. Monogr. 68: 295-323.

Duelli P. and Obrist M.K. 1998. In search of the best correlates for local organismal biodiversity in cultivated areas. Biodiv. Conserv. 7: 297-309.

Dufrêne M. and Legendre P. 1997. Species assemblages and indicator species: the need of a flexible asymmetrical approach. Ecol. Monogr. 67: 345-366.

Eggleton P., Bignell D.E., Hauser S., Dibog L., Norgrove L. and Madong B. 2002. Termite diversity across an anthropogenic disturbance gradient in the humid forest zone of West Africa. Agr. Ecosyst. Environ. 90: 189-202.

Elliott S., Blakesley D. and Anusaransunthron V. 1998. Forests for the Future - Growing and Planting Native Trees for Restoring Forest Ecosystems. Forest Restoration Research Unit. Chiang Mai University, Chiang Mai.

FAO. 2000. Global Forest Resources Assessment 2000. Main report, Rome.

FAO. 2001. State of the World's Forests 2001. Rome. 
FAO-UNESCO. 1974. Map of the World. Paris.

Fermon H., Schulze C.H., Waltert M. and Mühlenberg M. 2001. The butterfly fauna of the Noyau central, Lama Forest (Republic of Benin), with notes on its ecological composition and geographic distribution. Afr. Entomol. 9: 177-185.

Gemerden B.S.V., Shu G.N. and Olff H. 2003. Recovery of conservation values in Central African rain forest after logging and shifting cultivation. Biodiv. Conserv. 12: 1553-1570.

Giulio M.D., Edwards P.J. and Meister E. 2001. Enhancing insects in agricultural grasslands: the roles of management and landscape structure. J. Appl. Ecol. 38: 310-319.

Goodman S.M., Rakotondravony D., Schatz G. and Wilmé L. 1996. Species richness of forestdwelling birds, rodents and insectivores in a planted forest of native trees: a test case from Ankaratra, Madagascar. Ecotropica 2: 109-120.

Hill C.J. 1995. Linear strips of rain forest vegetation as potential dispersal corridors for rain forest insects. Conserv. Biol. 9: 1559-1566.

Hill M.O. and Gauch H.G.J. 1980. Detrended correspondance analysis: an improved ordination technique. Vegetatio 42: 47-58.

Holloway J.D., Kirk-Spriggs A.H. and Khen C.V. 1992. The response of some rain forest insect groups to logging and conversion to plantation. In: Marshall A.G. and Swaine M.D. (eds), Tropical Rain Forest: Disturbance and Recovery. Philosophical Transactions of the Royal Society of London Series B. 335: 425-436.

Jennrich R.I. and Turner F.B. 1969. Measurement of non-circular home range. J. Theor. Biol. 22: $227-237$.

Kalif K.A.B., Azevedo-Ramos C., Moutinho P. and Malcher S.A.O. 2001. The effect of logging on the ground-foraging ant community in eastern Amazonia. Stud. Neotrop. Fauna Environ. 36: 15 .

Kapos V. 1989. Effects of isolation on the water status of forest patches in the Brazilian Amazon. J. Trop. Ecol. 5: 173-185.

Klein B. 1989. Effects of forest fragmentation on dung and carrion beetle communities in central Amazonia. Ecology 70: 1715-1725.

Lamb D. 1998. Large-scale ecological restoration of degraded tropical forest lands: the potential role of timber plantations. Restor. Ecol. 6: 271-279.

Laurance W.F., Lovejoy T.E., Vasconcelos H.L., Bruna E.M., Didham R.K., Stouffer P.C., Gascon C., Bierregaard R.O., Laurance S.G. and Sampaio E. 2002. Ecosystem decay of Amazonian forest fragments: a 22-year investigation. Conserv. Biol. 16: 605-618.

Lawton J.H., Bignell D.E., Bolton B., Bloemers G.F., Eggleton P., Hammond P.M., Hodda M., Holt R.D., Larsen T.B., Mawdsley N.A., Stork N.E., Srivastava D.S. and Watt A.D. 1998. Biodiversity inventories, indicator taxa and effects of habitat modification in tropical forest. Nature 391: 72-76.

Lee S.-M. and Chao A. 1994. Estimating population size via sample coverage for closed capturerecapture models. Biometrics 50: 88-97.

Mantel N. 1967. The detection of disease clustering and a generalized regression approach. Cancer Res. 27: 209-221.

McCune B. and Mefford M.J. 1999. PC-ORD: Multivariate Analysis of Ecological Data. MjM Software Design, Gleneden Beach, Oregon.

Mühlenberg M. 1993. Freilandökologie. UTB für Wissenschaft. Quelle und Meyer Heidelberg, Wiesbach.

Myers N., Mittermeier R.A., Mittermeier C.G., d. Fonseca G.A.B. and Kent J. 2000. Biodiversity hotspots for conservation priorities. Nature 403: 853-858.

New T.R. 1998. Invertebrate Surveys for Conservation. Oxford, Oxford University Press.

Nummelin M. and Hanski I. 1989. Dung beetles of the Kibale Forest, Uganda; comparison between virgin and managed forests. J. Trop. Ecol. 5: 349-352.

Rainio J. and Niemelä J. 2003. Ground beetles (Coleoptera: Carabidae) as bioindicators. Biodiv. Conserv. 12: 487-506. 
Sayer J.A., Harcourt C.S. and Collins N.M. 1992. The Conservation Atlas of Tropical Forests. Africa. IUCN, New York.

Southwood T.R.E. 1978. Ecological Methods: with Particular Reference to the Study of Insect Population. Chapman and Hall, London, New-York.

Specht I. 2002. La forêt de la Lama, Bénin-SIG basé sur Landsat 7. Opuscula Biogeographica Basileensia 2. Basel, Switzerland.

Speight M.R. and Wylie F.R. 2001. Insect Pests in Tropical Forestry. CABI Publishing, Oxford, Brisbane.

Stanton N.L. 1979. Patterns of species diversity in the temperate and tropical litter mites. Ecology 60: 295-304.

Stork N.E., Srivastava D.S., Watt A.D. and Larsen T.B. 2003. Butterfly diversity and silvicultural practice in lowland rainforests of Cameroon. Biodiv. Conserv. 12: 387-410.

Townes H. 1972. A light-weight malaise trap. Entomol. News 83: 239-247.

Tucker N. and Murphy T. 1997. The effect of ecological rehabilitation on vegetation recruitment: some observations from the wet tropics of North Queensland. Forest Ecol. Manage. 99: 133-152.

Vasconcelos H.L., Vilhena J.M.S. and Caliri G.J.A. 2000. Responses of ants to selective logging of a central Amazonian forest. J. Appl. Ecol. 37: 508-514.

Watt A.D., Stork N.E., McBeeath C. and Lawson G.L. 1997. Impact of forest management on insect abundance and damage in a lowland tropical forest in southern Cameroon. J. Appl. Ecol. 34: $985-998$.

White F. 1983. The Vegetation of Africa. UNESCO, Paris.

Wilkening A.J., Foltz J.L., Atkinson T.H. and Connor M.D. 1981. An omnidirectional flight trap for ascending and descending insects. Can. Entomol. 113: 453-455.

Whittaker R.H. 1960. Vegetation of the Siskiyou Mountains, Oregon and California. Ecol. Monogr. 30: 279-338.

Zapfack L., Engwald S., Sonke B., Achoundong G. and Madong B.A. 2002. The impact of land conversion on plant biodiversity in the forest zone of Cameroon. Biodiv. Conserv. 11: 20472061.

Zar J.H. 1999. Biostatistical Analysis. Pearson Education, New Jersey. 


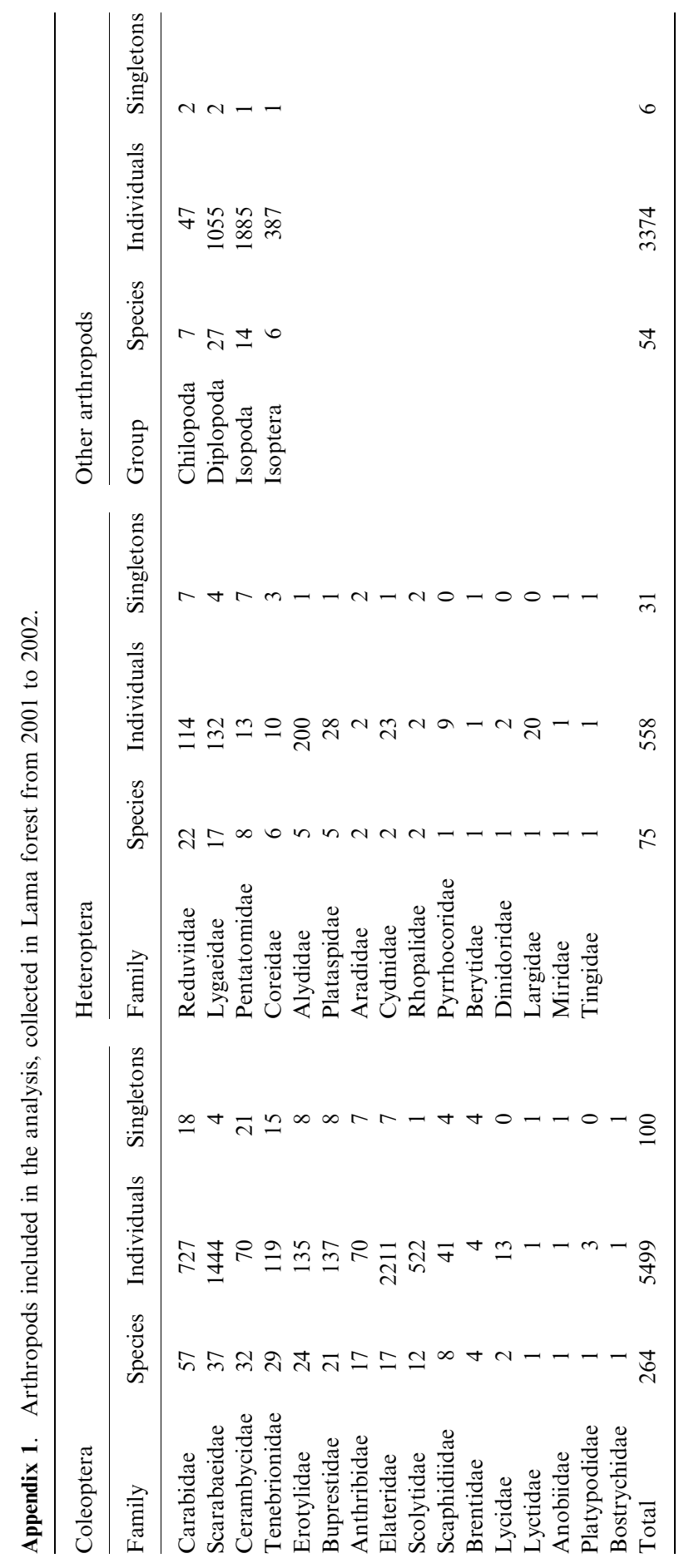

